


\section{WHY BINGE-WATCHING? THE PROMINENT MOTIVES AND ANALYSIS OF THE MOTIVATING HEDONIC AND EUDAIMONIC ELEMENTS OF EMOTIONAL GRATIFICATION IN A BINGE-WATCHING EXPERIENCE}

\section{Vesna Karuza Podgorelec}

ORIGINAL SCIENTIFIC PAPER/ DOI: https://doi.org/10.20901/ms.11.21.1/ SUBMITTED: 30.1.2020.

ABSTRACT Binge-watching is a popular form of media consumption, and entertainment is one of the main drivers of this activity. This research aims to examine the prominent reasons for binge-watching by re-examining the established television viewing motives, by deepening the analysis of entertainment motives, and by introducing a new possible motive - the need for narrative understanding. Therefore, the researcher combines the factors of the established television viewing motives, the factors of hedonic and eudaimonic emotional gratification in an entertainment experience and introduces the motive of the ease of following storylines. The results of an online survey with 833 participants over the age of eighteen conducted in Croatia suggest that the motives of relaxation, fun (hedonic), habit, easier following of intricate storylines, escape, and thrill (hedonic) are prominent. Eudaimonic motives are less pronounced than hedonic ones, however, these clusters are positively related, which indicates the complexity of enjoyment in binge-watching entertainment.

KEYWORDS

BINGE-WATCHING, EMOTIONAL GRATIFICATION, MEDIA HABITS, MOTIVATION, AUDIENCE STUDIES

Author note

Vesna Karuza Podgorelec :: University of Josip Juraj Strossmayer in Osijek, Croatia :: vesnakaruzapodgorelec@gmail.com 


\section{INTRODUCTION}

An increasingly popular way of watching a television series is to stream it from video-on-demand (VoD) services and to watch multiple episodes of the same series consecutively. This practice, well-known as 'binge-watching', is becoming 'the New Normal' (Netflix, 2013) not only among the young audience. In the USA in $2017,91 \%$ of Generation Z, $86 \%$ of Millennials and $80 \%$ of Generation X claimed that they were bingewatching (Deloitte, 2018: 12). European middle-aged and older people also practice this mode of media consumption (Ampere Analysis, 2018). The 2018 data about people who 'frequently binge' indicate that binge-watching is standard practice for more than $63 \%$ of the USA and 51\% of European viewers (Advanced Television, 2018). The burgeoning streaming industry reshaped the traditional broadcasting logic and raised the profile of binge-watching. In 2013, Netflix began with a distinctively different way of delivering streaming-oriented TV series that encourages binge-watching. They released complete seasons of highly serialised original content, which is expensive to produce and difficult to monetise in the traditional way (Jenner, 2015; Tryon, 2015), by connecting this practice with quality television and a "promise of prestige, plenitude, and participation" (Tryon, 2015: 105). Just three years later, Lotz (2015) argued that "2015 was the year that changed TV forever", pointing out that digital distribution had driven profound changes in audience behaviour. Nowadays "binging is more than just an audience reception practice. It is an integral part of an emergent streaming industry" (Burroughs, 2019: 8). Due to the increasing popularity of streaming practices and the binge-watching phenomenon, media companies must radically "realign the ways in which content is imagined, formulated, financed, produced, promoted, packaged, marketed, measured, delivered, interpreted, enjoyed, and recirculated" (Curtin et al., 2014: 4-5; see also: Burroughs, 2019).

To understand mediated communications, we must "understand the characteristics, motivation, selectivity, and involvement of audience members" (Rubin, 2002: 526). If we want to figure out why binge-watching has become such a cultural phenomenon, it is essential to explore why this mode of viewing television series is resonating with today's viewers. Therefore, I explored binge-watching from the perspective of the audiences' motives. To do so, I applied the uses and gratifications (U \& G) theory and the entertainment theory as my guiding framework. Both approaches address the social and psychological aspects of an audience's motives for particular media consumption (Bryant et al., 2003; Katz et al., 1973). Entertainment is one of the prominent television viewing motives of both traditional television (Rubin, 1983), and Internet protocol television (IPTV; Kim and Lee, 2013) and enjoyment is a focal concept in entertainment theory (Tamborini et al., 2011: 1025). The recent research provided evidence for two processes of entertainment experiences which lead to enjoyment and emotional gratifications: a hedonic one related to pleasure, suspense, or fun; and a eudaimonic one, associated with the feelings of appreciation, elevation, and inspiration (Oliver and Bartsch, 2010; Tamborini et al., 2011; Vorderer et al., 2004; Wirth et al., 2012). Likewise, Busselle and Bilandzic (2009) found that narrative understanding is one of the four fundamental dimensions of narrative

\footnotetext{
${ }^{1}$ The research presented in this paper is part of an extensive study of binge-watching which, apart from the binge-watching motives, examines telepresence, transportation, and identification during binge-watching.
} 
engagement that lead to greater enjoyment. To better understand how television is perceived technologically and culturally, it is necessary to identify new viewing motives (Steiner and $\mathrm{Xu}, 2018$ ) and explore some of the established motives more deeply in line with new findings. The goal of this study is to research the reasons why individuals are bingewatching by re-examining the established television viewing motives, by expanding the research of the entertainment motive and by introducing the need for narrative understanding as a new possible motive. This perspective is reflected in the method that combines factors from the studies of television viewing motives, the factors from studies of emotional gratification in an entertainment experience of viewing fictional content and one specific category related to narrative enjoyment focused on narrative understanding as related to binge-watching. I hoped to find out which of these elements are prominent as motives for binge-watching and what the relations between entertainment motives are. By conducting research from this viewpoint, I aimed to contribute to the more indepth insight of binge-watching motives. The research was conducted in Croatia.

\section{BINGE-WATCHING MOTIVE RESEARCH}

Flayelle, et al. (2020) in a review of binge-watching quantitative studies, summarised two main clusters of prominent binge-watching motives. The first cluster includes hedonic motivations for the maximisation of enjoyable attributes of viewing (i.e., entertainment, enjoyment): "better engagement with the content, greater fan enthusiasm, deeper experience of suspense/anticipation, and stronger feeling of getting swept away in the story" (Flayelle et al., 2020: 48). Eudaimonic and reward-based motivations have also been found as important in the binge-watchers' involvement (Flayelle et al., 2020: 48). Thus, binge-watching may be "a highly rewarding and pleasurable experience that may drive deliberate and harmonious significant viewing involvement performed in response to various needs and desires" (Flayelle et al., 2020: 57). The second cluster of prominent motives "make binge-watching appear as-something rather compensatory" (Flayelle et al., 2020: 48). Frequent and prolonged binge-watching is associated with the motivations of passing time, dealing with loneliness, escape from everyday worries, procrastination, and emotion regulation purposes (Flayelle et al., 2020: 48). Maladaptive coping and selfregulation failure constitute significant predictors for binge-watching to become "an excessive/problematic behaviour not only associated with negative outcomes but also with a range of risk factors associated with the dysfunctional use of technologies (e.g., age, underlying coping motives, impulsivity, automaticity) and diverse mental health conditions" (Flayelle et al., 2020: 57). Flayelle et al. (2020: 57) suggest that "high but healthy engagement in TV series watching should be distinguished from problematic bingewatching to avoid pathologising this highly popular activity".

Some researchers used focus groups to better understand binge-watching motives. These findings are in line with the quantitative results. The prominent motives are immersion in stories, entertainment (Flayelle et al., 2017), anticipation of what was coming next, management of moods and excitement/arousal, and procrastination and escapism (Rubenking et al., 2018). Both focus groups' researchers also found social goals as a motive 
as well as some qualitative studies (see: Flayelle et al., 2020). The findings of Steiner and Xu's (2018) qualitative semi-structured interviews indicate that, besides immersion, viewers' motivations are: catching up (control time of entertainment), relaxation, the sense of completion (similar to the feeling when we finish a book), cultural inclusion, and the improved viewing experience.

\section{RESEARCH QUESTION AND HYPOTHESIS DEVELOPMENT}

Starting from the concept that people actively, and for a specific purpose, seek and select messages sent by the media, $U$ \& G theory describes and explains the motives, functions, and consequences of these choices. $U \& G$ tries to explain how people use media to gratify their needs, and gratification is conceptualised as the audiences' satisfaction when the media match their expectations and needs (Katz et al., 1973: 510-511). Rubin's (1983) pioneering work on audiences' TV-viewing motives suggested that viewers watched TV for relaxation, companionship, entertainment, social interaction, information, habit, passing the time, arousal, and escape. The entertainment motive is not prominent just for traditional television and IPTV but for binge-watching as well (e.g., Rubenking et al. 2018; Starosta et al. 2019; Sung et al., 2018). Entertainment theory combined several different theories including $U$ \& $G$ to describe and explain what entertainment is, how it works, how it influences the audience, and why the audience is so attracted to it (Vorderer, 2003: 132). Zillmann and Bryant (1994) contend that people consume entertaining content firstly to enjoy, and that enjoyment is achieved through emotional experiences (Bartsch et al., 2006; Bryant and Miron, 2002; Sherry, 2004; Zillmann and Bryant, 1994; Vorderer et al., 2006). TV series also affect the audience primarily through emotion (e.g., Oatley, 2011: 107-132). Individuals regulate their mood states by tending to choose fiction with strong positive hedonic qualities (Zillmann, 1988), yet enjoyment is not only associated with the satisfaction of hedonic needs (Tamborini et al., 2010; Tamborini et al., 2011). Entertainment researchers find that a substantial proportion of entertainment content can be characterised as dramatic, poignant, tragic, or touching (Oliver, 2008: 55). Oliver discovers that sadness (1993) and tender affective states like warmth, sympathy, and understanding (2008) are connected to a greater interest in watching movies and TV series, as well as with creating the feeling of enjoyment. Therefore, aside from the pleasure-seeking hedonic motives, people also consume entertainment because of their 'truth-seeking' eudaimonic motivations. Entertainment can be used "as a means of grappling with questions such as life's purpose and human meaningfulness" (Oliver and Raney, 2011: 984). Contemplative experiences, vicarious release of emotions, empathic sadness, social sharing of emotions, and character engagement can be binge-watching motives just like fun and thrill (cf., Bartsch, 2012). Some researchers (e.g., Tukachinsky and Eyal, 2018) find that bingewatching may be more related to eudaimonic than to hedonic enjoyment.

Binge-watching on VoD platforms is connected with the 'Netflix effect' because Netflix do not only deliver content differently. They have created an original quality drama brand identity and offer an innovative approach to watching series through a change in format, a narrative perspective, and narrative structure (Jenner, 2015). A 'binge-worthy' 
serialised narratives has an intriguing indivisible narrative arc and complex storylines with clues and narrative enigmas that require a highly active mode of cognitive engagement (Mittell, 2007: 170; cf., Burroughs, 2019). During binge-watching, viewers feel cognitively and emotionally active (Tukachinsky and Eyal, 2018.), engaged and immersed in the storyworld (Harris Pool, 2013; Starosta et al. 2019). Therefore, binge-watching may be motivated by the very structure of television series offered on the VoD platforms.

Recent research into the motive of binge-watching has been largely focused on Generation Z and Millennials (e.g., Flayelle et al., 2017; Panda and Pandey, 2017; Pittman and Sheehan, 2015; Rubenking and Bracken, 2018; Rubenking et al., 2018; Shim and Kim, 2018; Starosta et al., 2019; Walton-Pattison et al., 2016; for an overview, see: Flayelle et al., 2020). Earlier studies of television viewing motivations (e.g., Rubin and Rubin, 1981) indicate that age is an influential factor in determining viewing motivations. With this reasoning in mind, the current study addresses the following research question to examine bingewatching motives among wider audiences:

Research question: What motivates audiences over the age of eighteen to binge-watch?

Viewers achieve emotional pleasure and enjoyment by escaping into a fantasy world within which they experience a wide range of pleasant and unpleasant emotions (Sherry, 2004). Because of that, an emotional experience gained during fiction consumption can evoke complex and multifaceted feelings (Bartsch, 2012; Oliver and Bartsch, 2010, 2011; Oliver and Hartman, 2010; Oliver and Raney, 2011). Happiness and sadness are simultaneous, and meta-emotions (Oliver, 1993), meaningfulness, compassion, inspiration, introspection, and contemplativeness (Oliver, 2008) are present as well. Sherry (2004: 330) points out that "entertainment is a multifaceted construct" in which "pleasure and pain, as well as arousal and relaxation, are neither mutually exclusive nor polar opposites." Therefore, I formulated the hypothesis as follows:

Hypothesis: The hedonic and eudaimonic binge-watching motives are positively correlated in a population over the age of eighteen.

\section{METHOD}

\section{Participants}

The data from 833 participants over the age of eighteen were analysed. Approximately four-fifths of the sample (80.6\%) identified as women, $19 \%$ as men, and $0.4 \%$ did not want to declare their gender. Approximately $1 / 2$ of the sample are Generation $X$ aged 38-52 (50.2\%), and approximately one-fourth of the sample are Millennials aged 24-37 (27.3\%), followed by the Generation Z sample younger than 23 (11.5\%), and Baby Boomers older than 53 (10.9\%). Approximately one-half of the participants reported some college education (52.9\%), followed by participants with a high school diploma (16.9\%), college students (16.8\%), people with a PhD degree or PhD candidates (13\%), high school students 
(0.2\%), and participants with an elementary school certificate (0.1\%). Table 1 contains descriptive data about participants.

Table 1. Descriptive statistics about participants

\begin{tabular}{lll} 
Variable & Frequency & Percentage \\
Gender & & 19 \\
\hline Men & 158 & 80.6 \\
Women & 671 & 0.4 \\
Do not want to declare gender & 3 & 100 \\
Total & 832 & \\
Age & & 11.5 \\
\hline $18-23$ & 96 & 27.3 \\
$24-37$ & 227 & 50.2 \\
$38-52$ & 418 & 10.9 \\
53 and older & 91 & 100 \\
Total & 832 & \\
Education & & 0.2 \\
\hline High school student & 2 & 16.8 \\
College student & 140 & 0.1 \\
Elementary school certificate & 1 & 16.9 \\
High school diploma & 141 & 52.9 \\
College education & 441 & 13 \\
PhD degree or PhD candidate & 108 & 100 \\
Total & 833 & \\
\hline
\end{tabular}

\section{Procedure}

Previous researchers identified motivational factors using different conceptualisations of binge-watching (for an overview, see: Flayelle et al., 2020). Based on research into audience habits, Netflix (2013) defined binge-watching as the watching of two and more episodes of the same TV show in one sitting. The minimum limit of two episodes in one sitting is also set by Pittman and Sheehan (2015), Mikos (2016), Walton-Pattison et al. (2016), Panda and Pandey (2017), and Sung et al. (2018). For this research, I also defined bingewatching as a consecutive watching of at least two episodes of the same television series.

An online survey was conducted during May 2019 using a poll distributed via Facebook and the websites of Josip Juraj Strossmayer University of Osijek and the University of Dubrovnik. The respondents answered questions by citing the memories of the series that they had watched. The researcher asked the respondents to forward the link of the survey to other people who they knew were binge-watching. Therefore, the approach to the sample selection has the characteristics of chain referral sampling or snowball methods. 
According to Biernacki and Waldorf (1981: 141), this sampling method is suitable when a study requires the knowledge of insiders to locate people for the study. Facebook, mainly because its users are connected to people of similar interests and characteristics, can serve as a useful sampling tool for populations that tend to be found with more difficulty by means of traditional methods (Brickman-Bhutta, 2012). Baltar and Brunet (2012) showed that virtual snowball sampling via Facebook could be an excellent substitute for obtaining data through more expensive procedures. A total of 873 respondents completed the survey.

\section{Analysis}

The data were analysed using the SPSS software (IBM Corp. Released 2017. IBM SPSS Statistics for Windows, Version 25.0. Armonk, NY: IBM Corp). The factor structure of the used scales was assessed using confirmatory factor analyses with correlated factors. Due to the violation of multivariate normality and usage of ordinal data, a ULSM estimator was used. The optimal structure was additionally assessed with exploratory analyses, namely a principal component analysis with oblimin rotation. The data is suitable for factor analysis, as evidenced by high KMO values (.795 for Rubin's, 1983 scale; .913 for Bartsch's, 2012 scale) and significant Bartlett's tests of sphericity $(p<.001)$. The descriptive results are presented through means and standard deviations. The associations between the variables were determined with Pearson's coefficients of correlation. Alpha values were set to $5 \%(a=.05)$. Participants lacking up to one or two responses had their answers imputed using the 'expectation-maximization' method. Participants who lacked more data were not included in the analysis. After removing the survey forms incorrectly filled out, 833 responses entered the analysis process.

\section{Instruments and scales}

In $U$ \& $G$ motive research, many motives were identified through the use of the pre-existing measures for different media channels (e.g., Papacharissi and Rubin, 2000; Haridakis and Hanson, 2009; Papacharissi and Mendelson, 2007). This study was designed according to two pre-existing scales: Rubin's (1983) television viewing motives' scale and Bartsch's (2012) emotional gratification in entertainment experience scale. Rubin's (1983) scale is structured by nine factors (each with three segments). Six of them are included in this study: relaxation, companionship, passing time, habit, social interaction, and escape. Entertainment, information, and arousal were excluded. The 'information' motive was eliminated because the original structure of this factor extracts statements about the informative and practical value of television content, which literature does not cite as dominant for fictional narratives, such as: "... So I can learn how to do things which I haven't done before." (Rubin, 1983: 41). Earlier studies of binge-watching motives indicated a small presence of this factor (e.g., Starosta et al., 2019; Sung et al., 2018). I also wanted to explore the motives of entertainment and arousal in more detail. Therefore, instead of Rubin's 'entertainment' and 'arousal' factors, Bartsch's (2012) scale of emotional gratification in the entertainment experience was introduced. By using Bartsch's scale (2012), designed to study the emotional gratification associated with TV series and movies, I wanted to explore the entertainment motives associated with fictional content through the prism 
of cognitive-emotional experience, separating the hedonic and eudaimonic motivations that generate enjoyment.

A confirmatory factor analysis of Rubin's scale indicates a good model fit (CFI = 0.975 , RMSEA $=0.064$ ). A principal component analysis confirmed the original structure, grouping items into six predicted components with high component loadings only on the desired components. The components are (each represented with three items): relaxation (Cronbach's $a=0.85)$, companionship ( $a=0.85)$, social interaction $(a=0.71)$, habit ( $a$ $=0.85)$, passing time $(a=0.85)$, and escape $(a=0.64)$. Originally, Bartsch performed $a$ principal component analysis with a varimax rotation. A confirmatory factor analysis of Bartsch's scale with uncorrelated factors indicated a poor fit (CFI $=0.390$, RMSEA $=$ 0.375 ), so another one was performed with correlated factors, resulting in a good fit (CFI $=0.987$, RMSEA $=0.056$ ). A principal component analysis was performed with an oblimin rotation instead of a varimax, grouping items into seven predicted components with high component loadings only on the desired components. The components are (each represented with four items): contemplative experiences $(\alpha=0.90)$, vicarious release of emotions ( $a=0.92)$, empathic sadness ( $a=0.82)$, social sharing of emotions $(a=0.85)$, character engagement $(\alpha=0.84)$, fun $(\alpha=0.92)$, and thrill $(a=0.87)$. Along with Bartsch's and Rubin's scales, one more construct was examined - the ease of following storylines. It was tested by using one item: "I binge-watch because it allows me to follow intricate storylines more easily."

The respondents expressed their level of agreement with the items using a five-point Likert-type scale ranging from 1 ("strongly disagree") to 5 ("strongly agree"). The total subscale scores were calculated as a mean of the items pertaining to the subscale. A score higher than the neutral value of 3 indicates that the particular element is prominent as a binge-watching motive. The respondents also gave answers to questions about the frequency of binge-watching (with the following answers: "less than once a month", "once a month", "a few times a month", "once a week", "a few times a week", "every day") and the number of episodes watched per binge-watching session (with the following answers: "two to four episodes", "five to ten episodes", "a whole season", "more than one season"). Respondents also answered questions about their gender, age, and level of education. Tables 2 and 3 contain results of principal component analysis with oblimin rotation.

Table 2. Results of the principal component analysis with oblimin rotation (pattern matrix): Television viewing motives scale (according to Rubin, 1983)

\begin{tabular}{|c|c|c|c|c|c|c|}
\hline "I binge-watch..." & C1 & $\mathrm{C} 2$ & C3 & C4 & C5 & C6 \\
\hline $\begin{array}{l}\text { because series on demand are always } \\
\text { available. }\end{array}$ & 0.93 & 0.05 & -0.02 & 0.03 & 0.07 & -0.01 \\
\hline because I just like to binge. & 0.90 & 0.00 & 0.02 & -0.01 & -0.03 & 0.02 \\
\hline because it is my habit. & 0.76 & -0.02 & 0.01 & -0.10 & -0.11 & 0.03 \\
\hline because it relaxes me. & -0.02 & 0.91 & 0.00 & 0.03 & -0.02 & 0.01 \\
\hline because it is a pleasant rest. & 0.07 & 0.84 & 0.01 & 0.00 & 0.03 & 0.06 \\
\hline because it allows me to unwind. & -0.01 & 0.83 & 0.00 & -0.08 & -0.08 & -0.02 \\
\hline
\end{tabular}




\begin{tabular}{|c|c|c|c|c|c|c|}
\hline „I binge-watch..." & C1 & $\mathrm{C} 2$ & $\mathrm{C} 3$ & C4 & C5 & C6 \\
\hline when my friends come over. & 0.08 & 0.00 & 0.82 & 0.01 & -0.02 & -0.13 \\
\hline $\begin{array}{l}\text { so I can talk with others who are } \\
\text { binging. }\end{array}$ & 0.01 & -0.09 & 0.80 & -0.07 & -0.04 & 0.17 \\
\hline $\begin{array}{l}\text { because I like binging with my family } \\
\text { or friends. }\end{array}$ & -0.09 & 0.08 & 0.79 & 0.04 & 0.05 & -0.01 \\
\hline $\begin{array}{l}\text { so I can get away from everybody and } \\
\text { have time for myself. }\end{array}$ & 0.00 & 0.01 & 0.00 & -0.92 & 0.05 & 0.02 \\
\hline $\begin{array}{l}\text { so I can unplug myself from } \\
\text { everything. }\end{array}$ & 0.03 & 0.03 & -0.04 & -0.91 & 0.03 & 0.02 \\
\hline $\begin{array}{l}\text { so I can forget about my daily } \\
\text { obligations. }\end{array}$ & 0.01 & -0.02 & 0.04 & -0.86 & -0.07 & -0.04 \\
\hline because I will not have to be alone. & -0.13 & 0.05 & -0.01 & -0.04 & -0.94 & -0.01 \\
\hline $\begin{array}{l}\text { when there is no one else to talk to } \\
\text { or be with. }\end{array}$ & 0.01 & 0.01 & 0.00 & -0.03 & -0.91 & 0.01 \\
\hline because it makes me feel less lonely. & 0.21 & 0.01 & 0.03 & 0.08 & -0.73 & 0.03 \\
\hline $\begin{array}{l}\text { because it gives me something to do } \\
\text { to occupy my time. }\end{array}$ & 0.13 & 0.10 & 0.04 & 0.02 & 0.01 & 0.76 \\
\hline when I have nothing better to do. & 0.02 & -0.13 & -0.04 & 0.01 & -0.08 & 0.73 \\
\hline when I am bored. & -0.13 & 0.18 & 0.03 & -0.05 & 0.08 & 0.73 \\
\hline$\lambda$ & 4.65 & 2.66 & 1.82 & 1.68 & 1.33 & 1.21 \\
\hline$\%$ & 25.86 & 14.79 & 10.12 & 9.36 & 7.41 & 6.69 \\
\hline$a$ & 0.86 & 0.85 & 0.71 & 0.88 & 0.85 & 0.64 \\
\hline
\end{tabular}

Note: $\lambda$ - eigenvalue, $\%$ - explained variance, $a$ - Cronbach's alpha. Component loadings higher than 0.4 are bolded. Items belonging to different components are separated by horizontal line. C1 - habit, C2 - relaxation, C3 - social interaction, C4 - escape, C5 - companionship, C6 - pastime.

Table 3. Results of the principal component analysis with oblimin rotation (pattern matrix): Emotional gratification scale (according to Bartsch, 2012)

\begin{tabular}{|c|c|c|c|c|c|c|c|}
\hline "I binge-watch because..." & $\mathrm{C} 1$ & $\mathrm{C} 2$ & C3 & C4 & C5 & C6 & C7 \\
\hline $\begin{array}{l}\text { I can experience the feelings that } \\
\text { are difficult for me to allow myself in } \\
\text { everyday life. }\end{array}$ & 0.94 & 0.01 & -0.01 & 0.00 & 0.00 & 0.02 & 0.00 \\
\hline $\begin{array}{l}\text { it allows me to experience feelings } \\
\text { that I normally have to hide in } \\
\text { everyday life. }\end{array}$ & 0.94 & 0.00 & -0.03 & 0.03 & -0.03 & 0.03 & 0.02 \\
\hline $\begin{array}{l}\text { it allows me to experience emotions } \\
\text { that I avoid in everyday life. }\end{array}$ & 0.93 & 0.02 & 0.01 & -0.04 & -0.02 & -0.01 & 0.00 \\
\hline $\begin{array}{l}\text { it allows me to experience feelings } \\
\text { that I cannot act on in everyday life. }\end{array}$ & 0.72 & 0.00 & 0.04 & -0.02 & 0.10 & -0.04 & -0.12 \\
\hline it puts me in a good mood. & -0.01 & 0.88 & 0.03 & -0.01 & -0.02 & 0.01 & -0.03 \\
\hline it is funny. & 0.00 & 0.84 & 0.03 & -0.13 & 0.06 & -0.01 & 0.08 \\
\hline
\end{tabular}




\begin{tabular}{|c|c|c|c|c|c|c|c|}
\hline „I binge-watch because...." & C1 & $\mathrm{C} 2$ & C3 & $\mathrm{C} 4$ & C5 & $\mathrm{C} 6$ & C6 \\
\hline it amuses me. & 0.01 & 0.82 & -0.06 & -0.14 & -0.03 & 0.00 & 0.04 \\
\hline it makes me laugh. & 0.02 & 0.73 & 0.05 & 0.24 & 0.03 & 0.05 & -0.09 \\
\hline $\begin{array}{l}\text { it inspires me to think about } \\
\text { meaningful issues. }\end{array}$ & 0.00 & -0.01 & 0.92 & -0.03 & -0.03 & 0.01 & -0.04 \\
\hline $\begin{array}{l}\text { it encourages me to focus on things } \\
\text { that are important to me. }\end{array}$ & -0.01 & 0.02 & 0.83 & -0.04 & -0.02 & -0.01 & 0.07 \\
\hline it inspires new insights. & -0.02 & 0.02 & 0.83 & -0.06 & 0.00 & 0.08 & -0.04 \\
\hline it makes me think about myself. & 0.05 & 0.02 & 0.82 & 0.03 & 0.07 & -0.03 & -0.10 \\
\hline it is more exciting, and I like that. & 0.02 & 0.04 & 0.01 & -0.90 & 0.02 & 0.04 & 0.02 \\
\hline $\begin{array}{l}\text { I like the tension created by that way } \\
\text { of viewing. }\end{array}$ & 0.02 & 0.04 & 0.00 & -0.85 & 0.05 & 0.03 & -0.04 \\
\hline $\begin{array}{l}\text { that way of viewing thrills my mind, } \\
\text { and I like that. }\end{array}$ & 0.01 & 0.01 & 0.12 & -0.83 & 0.02 & 0.02 & -0.04 \\
\hline I like the adrenaline I get from it. & 0.06 & 0.01 & 0.07 & -0.74 & 0.03 & 0.02 & -0.11 \\
\hline $\begin{array}{l}\text { when I binge, I identify myself with } \\
\text { the characters' outlook on life. }\end{array}$ & 0.02 & 0.02 & 0.03 & -0.01 & 0.86 & 0.00 & 0.01 \\
\hline $\begin{array}{l}\text { when I binge, I like to slip into the } \\
\text { role of characters. }\end{array}$ & 0.10 & 0.03 & -0.06 & -0.07 & 0.85 & -0.04 & 0.04 \\
\hline $\begin{array}{l}\text { when I binge, I may live through and } \\
\text { share the characters' experiences. }\end{array}$ & 0.05 & -0.09 & 0.18 & 0.04 & 0.70 & 0.11 & 0.10 \\
\hline when I binge, I feel with characters. & -0.10 & 0.08 & -0.10 & -0.04 & 0.66 & 0.03 & -0.23 \\
\hline $\begin{array}{l}\text { it stimulates the exchange of } \\
\text { comments while watching the series. }\end{array}$ & -0.05 & 0.02 & -0.05 & 0.03 & -0.02 & 0.94 & 0.00 \\
\hline $\begin{array}{l}\text { it inspires me to talk about the series } \\
\text { with others. }\end{array}$ & 0.02 & 0.07 & -0.01 & 0.02 & 0.01 & 0.90 & 0.01 \\
\hline $\begin{array}{l}\text { it encourages me to discuss issues } \\
\text { with others. }\end{array}$ & 0.02 & -0.03 & 0.08 & 0.02 & 0.03 & 0.86 & -0.04 \\
\hline $\begin{array}{l}\text { I am curious to find out what kind of } \\
\text { experience it is. }\end{array}$ & 0.11 & -0.06 & 0.06 & -0.20 & 0.05 & 0.55 & 0.01 \\
\hline I am moved by the story, and I like it. & 0.05 & 0.04 & 0.12 & 0.01 & 0.00 & 0.02 & -0.78 \\
\hline $\begin{array}{l}\text { I am overwhelmed by emotions, and } \\
\text { I like it. }\end{array}$ & 0.04 & 0.03 & 0.05 & -0.13 & 0.09 & -0.04 & -0.77 \\
\hline I may have a good cry, and I like it. & 0.10 & 0.00 & 0.06 & 0.12 & 0.07 & 0.03 & -0.76 \\
\hline it can be dramatic, and I like it. & 0.01 & -0.03 & -0.09 & -0.27 & -0.06 & 0.11 & -0.68 \\
\hline$\lambda$ & 9.79 & 2.55 & 2.23 & 2.17 & 1.65 & 1.42 & 1.29 \\
\hline$\%$ & 35.0 & 9.10 & 7.95 & 7.74 & 5.89 & 5.06 & 4.60 \\
\hline$a$ & 0.93 & 0.92 & 0.90 & 0.87 & 0.84 & 0.85 & 0.82 \\
\hline
\end{tabular}

Note: $\lambda$ - eigenvalue, \% - explained variance, a - Cronbach's alpha. Component loadings higher than 0.4 are bolded. Items belonging to different components are separated by horizontal line. $\mathrm{C} 1$ - vicarious release of emotions, C2 - fun, C3 - contemplative experiences, C4 - thrill, C5 - character engagement, C6 - social sharing of emotions, C7 - empathic sadness. 


\section{RESULTS}

Almost three-fourths of the respondents answered saying that they watched two to four episodes in one session (73.8\%). Answers denoting higher numbers of episodes are less prevalent, with five to ten episodes watched by under one-fifth of the respondents $(16.05 \%)$, whole seasons watched by less than a tenth $(8.6 \%)$, and only a small fraction watching more than a whole season (1.6\%). The largest number of respondents reported binge-watching less than once a month (28\%), followed by "a few times a month" (22.4\%), "a few times a week" (18.7\%), "once a month" (15.4\%), "once a week" (12.8\%), and finally "every day" (2.8\%). Overall, the respondents tended toward answers representing a lower frequency of binge-watching. Both the mean and the median suggest that the value that best represents the amount of binge-watching for the sample is "two to four episodes" $(M=1.38, S D=0.71, C=1, I Q R=1)$, and the value that best represents binge-watching frequency is "a few times a month" $(M=2.87, S D=1.54, C=3, I Q R=3)$. Table 4 contains the descriptive results of the amount and frequency of binge-watching.

Table 4. Descriptive statistic for the amount and frequency of binge-watching

\begin{tabular}{lll} 
Variable & Frequency & Percentage \\
Amount of binge-watching in one session & & \\
\hline Two to four episodes & 612 & 73.8 \\
Five to ten episodes & 133 & 16 \\
A whole season & 71 & 8.6 \\
More than one season & 13 & 1.6 \\
Total & 829 & 100 \\
Frequency of binge-watching & & \\
\hline Less than once a month & 232 & 28 \\
Once a month & 128 & 15.4 \\
A few times a month & 186 & 22.4 \\
Once a week & 106 & 12.8 \\
A few times a week & 155 & 18.7 \\
Every day & 23 & 2.8 \\
Total & 830 & 100 \\
\hline
\end{tabular}

Easier following of storylines is one of the pronounced motives for binge-watching, with an average rating higher than the neutral value of $3(M=3.54 ; S D=1.22)$. Among the established television viewing motives, those rated higher than the neutral value of 3 were: relaxation $(M=3.99, S D=0.83)$, habit $(M=3.59, S D=0.86)$, and escape $(M=3.37, S D$ $=1.15)$. The motive to pass time $(M=2.87, \mathrm{SD}=1.12)$ and the motives of social interaction $(M=1.93, S D=0.87)$ and companionship $(M=1.86, S D=0.98)$ were not pronounced.

Among the emotional gratification motives, a rating higher than the neutral value of 3 was achieved by hedonic motives: fun $(M=3.90, S D=0.71)$ and thrill $(M=3.04, S D=1.15)$. 
Eudaimonic motives of character engagement $(M=2.97, S D=0.87)$ and empathic sadness $(M=2.91, S D=0.98)$ were slightly less pronounced than the neutral value. Social sharing of emotions $(M=2.54, S D=1.04)$, contemplative experiences $(M=2.30, S D=0.99)$, and vicarious release of emotions $(M=1.90, S D=0.96)$ were not pronounced. Table 5 contains the descriptive results of the measured variables.

Table 5. Descriptive statistic and one-sample t-tests for the variables

\begin{tabular}{llll} 
Variables & M & SD & N \\
Television viewing motive & & & \\
\hline To pass time & 2.87 & 1.12 & 833 \\
Relaxation & 3.99 & 0.83 & 833 \\
Social interaction & 1.93 & 0.87 & 833 \\
Escape & 3.37 & 1.15 & 833 \\
Companionship & 1.86 & 0.98 & 833 \\
Habit & 3.59 & 0.86 & 833 \\
Emotional gratification motive & & & \\
\hline Vicarious release of emotions & 1.90 & 0.96 & 833 \\
Fun & 3.90 & 0.71 & 833 \\
Contemplative experiences & 2.30 & 0.99 & 833 \\
Thrill & 3.04 & 1.15 & 833 \\
Character engagement & 2.97 & 0.87 & 833 \\
Social sharing of emotions & 2.54 & 1.04 & 833 \\
Empathic sadness & 2.91 & 0.98 & 833 \\
\hline Easier following of the storylines motive & 3.54 & 1.22 & 833 \\
\hline Amount of episodes watched & 1.38 & 0.71 & 829 \\
\hline Frequency of binge-watching & 2.87 & 1.54 & 830 \\
\hline Note:M-m, & & & \\
\hline
\end{tabular}

Note: M - mean, SD - standard deviation.

Pearson's correlation coefficients between hedonic and eudaimonic motives show that the associations between these groups of motives are positive and statistically significant for all motives, which means that the participants with more pronounced hedonic motives also have more pronounced eudaimonic motives. The associations between the hedonic motive fun and eudaimonic motives have a small effect size $(r=.155, p<.001$ for vicarious release of emotions, $r=.215, p<.001$ for contemplative experiences, $r=.248, p<.001$ for character engagement, $r=.245, p<.001$ for social sharing of emotions, and $r=.261, p<$ .001 for empathic sadness). The associations between the hedonic motive thrill and the most eudaimonic motives are higher, with a moderately pronounced effect size $(r=.394$, $p<.001$ for vicarious release of emotions, $r=.393, p<.001$ for contemplative experiences, $r=.376, p<.001$ for character engagement, $r=.451, p<.001$ for social sharing of emotions), while the association between thrill and empathic sadness is greatly pronounced $(r=$ $.535, \mathrm{p}<.001$ ). Table 6 contains Pearson's correlation coefficients between hedonic and eudaimonic motives. 
Table 6. Pearson's correlation coefficients between hedonic and eudaimonic emotional gratification motives

\begin{tabular}{lll} 
Hedonic motives $(r)$ & Fun & Thrill \\
Eudaimonic motives & & \\
\hline Vicarious release of emotions & $.155^{*}$ & $.394^{*}$ \\
Contemplative experiences & $.215^{*}$ & $.393^{*}$ \\
Character engagement & $.248^{*}$ & $.376^{*}$ \\
Social sharing of emotions & $.245^{*}$ & $.451^{*}$ \\
Empathic sadness & $.261^{*}$ & $.535^{*}$ \\
\hline
\end{tabular}

Note: ${ }^{*} p<.001$

\section{DISCUSSION}

The results indicate that people binge-watch two to four episodes of a series a few times a month on average and that the pronounced (higher than the neutral value of 3) motives for binge-watching are: relaxation, fun, habit, easier following of the intricate storylines, escape, and thrill. Only a slightly lower than the neutral value (higher than $M=$ 2.90) are the eudaimonic motives of character engagement and empathic sadness. With these findings, I answered the research question about what motivates broad audiences older than the age of eighteen to binge-watch. The results suggest that binge-watching has become a habit that primarily gratifies the expectations for relaxation, fun and the escape from everyday routine by viewing of long-form series that are thrilling and with intricate storylines, and that people also appreciate character engagement and empathic sadness.

\section{Relaxation, escape and habit}

Among the participants, the relaxation, escape, and habit motives are prominent. Previous studies similarly discovered the prominence of habit (Rubenking and Bracken, 2018) and escapism as binge-watching motives (e.g., Panda and Pandey, 2017; Peña, 2015; Starosta et al., 2019; Vaterlaus et al., 2019), as well as the interconnection between binge-watching, relaxation and escapism (e.g., Jones et al., 2018; Peña, 2015). My findings also suggest that motives associated with loneliness, boredom, and social goals (e.g., pastime, social sharing of emotions, social interaction, and companionship, $M<2.9$ ) are not pronounced in a broad audience. The results of the study can be better understood by looking at previous findings. Flayelle et al. (2017), Panda and Pandey (2017), Pittman and Sheehan (2015), and Rubenking et al. (2018) point to the simultaneity of relaxation, high viewer engagement, and immersion in the narrative during binge-watching. Sung et al. (2018) and Erickson, Dal Cin, and Byl (2019) find that binge-watching is related to a stronger feeling of being "transported into a narrative word" (Green and Brock, 2000: 701) than traditional episodic TV viewing. Sherry (2004) argues that the state of optimal experience, or 'flow' (for an overview, see: Nakamura and Csikszentmihalyi, 2002), may explain a seemingly contradictory sensation of the pleasure of escaping from everyday 
routine achieved by simultaneous emotional stimulation and relaxation while consuming media content. The viewer's cognitive and affective engagement enables him/her to escape from everyday life, to travel into the storyworld while creating relaxation and pleasure (cf., Busselle and Bilandzic, 2009). The positive psychology's concept of 'flow'the healthy, pleasurable, relaxing and self-motivating experience of immersion in some activity, suggests that narrative transportation, the feeling of being 'lost' in the story (Nell, 1988: 8), is intrinsically rewarding (Green and Brock, 2002), and evokes a desire to feel this experience again (Nakamura and Csikszentmihalyi, 2002). LaRose (2010) notes that media habits are acquired through the repetition of certain behaviours that are initially started with some goal. My findings suggest that binge-watching among Croatian bingewatchers has become a common way to escape in a relaxing 'me time' activity. In the context of frequency and the number of episodes watched by the respondents, as well as the absence of pronounced motives associated with loneliness and boredom, the motive of escape from everyday life is not seen as an element that indicates problematic bingewatching, but as a way of realising personal satisfaction by escaping into the intimate world created by reading or watching fiction (cf., Rubin and Perse, 1987: 264).

\section{Hedonic and eudaimonic motives}

The results of the analysis of entertainment motives, split into hedonic and eudaimonic, indicate that the hedonic motives of fun and thrill are pronounced among Croatian bingewatchers. My findings support (a) mood management theory, based on the hedonic premise that individuals arrange media stimulus to maximise their good moods (Zillmann, 1988), and (b) the excitation transfer concept which states that transformation of uncomfortable feelings and excitement into positive emotions in the moment of a happy ending enhance feelings of euphoria (Zillmann, 1996). Our findings are consistent with previous binge-watching studies. Rubenking and Bracken (2018), and Rubenking et al. (2018) found that binge-watching is, first and foremost, a choice that is expected to result in fun. Flayelle et al. (2017: 464) consider that binge-watching could be an activity that serves to preserve and intensify a positive effect. Evoking emotions, especially positive ones, is an indispensable factor in the overall binge-watching experience. Rubenking et al. (2018: 81) also noticed that arousal experiences are stronger during binge-watching than episodic TV viewing.

None of the eudaimonic motives is prominent (they scored lower than the neutral value of 3). However, two of the eudaimonic motives - character engagement and empathic sadness - received average scores notably close to the neutral value of 3 ( $M$ $>2.9$ ). Among the specific items that measure character engagement, the item about empathy had a high score ("when I binge, I feel with characters"; $M=3.72$ ). Among the items that measure empathic sadness, the item about the positive evaluation of dramatic content also had a high score ("it can be dramatic, and I like it"; $M=3.38$ ). Due to this, I can conclude that the results point to the presence of eudaimonic motives that indicate the audience's appreciation of the increasingly empathic characters' engagement and empathic sadness through dramatic content. Previous research also found a connection between binge-watching and character engagement and dramatic content. Tukachinsky 
and Eyal (2018) establish that binge-watching was related to higher levels of identification with characters. Erickson et al. (2019) show that binge-watching builds a stronger and lasting parasocial relationships with the characters than episodic viewing. Flayelle et al. (2017: 466) find attachment to the characters to be an important part of the enjoyment of binge-watching, "reflecting the emotional investment that viewers placed in these stories". Rubenking et al. (2018) find that binge-watching is characterised as viewing suspenseful and dramatic content.

Correlational analysis results demonstrate that hedonic and eudaimonic motives are positively correlated. Such results confirm my hypothesis and this positive association affirms the complexity of entertainment. However, I find that thrill is more strongly associated with eudaimonic motives than fun, especially with empathic sadness. In addition to the research projects already mentioned, studies from the field of persuasive communication help explain this finding. Bartsch and Oliver (2011: 6) point out "set of the three factors that are directly related to the role of affect in motivated information processing": personal relevance, valence, and arousal. Dramas are perceived as a genre that provokes most thoughtfulness among viewers, and the experience of a dramatic narrative marks the joint appearance of positive and negative valence (Bartsch and Oliver 2011), or negative feelings follow positive meta-emotions (Oliver 1993). The inseparableness of hedonic and eudaimonic elements as motives for binge-watching can be connected to dramatic aspects and the complexity of the contents that viewers choose to binge-watch (Flayelle et al., 2017), as well as with the complex interplay of cognition and emotions during the entertainment experience (e.g., Bartsch and Oliver, 2011; Sherry, 2004).

\section{Following the intricate storylines}

My findings suggest that one of the prominent motives for binge-watching is easier following of intricate storylines. These findings are compatible with Pittman and Sheehan's (2015) results. Flayelle et al. (2017: 463) outline complex narratives, attractiveness from the very start, and innovative and serial structure as elements that contribute to bingewatching. Rubenking et al. (2018) find that the main motive of binge-watching is the continuous cycle of anticipation of further events by the viewer. The prominent motive of easier following of intricate storylines is linked to the anticipation motive because easier following of the narrative contributes to the anticipation of complex narratives during binge-watching and in this way participates in a stronger overall narrative engagement, which results in greater enjoyment (Busselle and Bilandzic, 2009).

\section{Limitations}

One of the limitations is the usage of the snowball sampling method. It can produce biased results because participants who invite each other into the study tend to be more similar than randomly sampled participants. Thus, the possibility of the generalisation of the whole Croatian population can be limited. This study, however, managed to include all age groups of Croats over the age of eighteen, with most of the sample consisting of middle-aged participants. They had been underrepresented in previous binge-watching studies. 
Another limitation concerns the method of data collection. The participants reported their binge-watching motives by citing the memories of the series that they had watched. The advantage of this method lies in the fact that participants were not presented specific, preselected TV series titles, therefore the research allowed them to report about the whole of their binge-watching experiences. The limitation of this method lies in the fact that the genre (McKinley, 2013; Slater and Rouner, 2002) and the narrative form (Flayelle et al., 2017) of the series can influence elements of emotional gratification as a motive for binge-watching. Therefore, the specifying of genres and the narrative structure of the examined series in a further study could lead to deeper insights. The focus of the study was to ascertain broad, main binge-watching motives, so I took into consideration a wide spectrum of genres and narrative structures, in accordance with other studies of this kind (e.g., Hall and Bracken, 2011; Shim and Kim, 2018; Starosta et al., 2019; Sung et al., 2018).

\section{CONCLUSION}

I hope that this research into the motives of binge-watching will contribute to a better understanding of the new media habits of Croatian as well as global audiences. The study included a broad population of binge-watchers among whom an important part is the middle-aged population, unlike the previous researches that mainly dealt with the motives of younger audiences. Our findings indicate the change in prominence of motivational factors in comparison to traditional TV viewing and episodic TV series viewing. The results suggest that binge-watching is a multifaceted phenomenon that maximizes the intrinsic rewarding and pleasurable attributes associated with watching TV series (above all hedonic and consequently eudaimonic). This intimate escape from everyday routine into fictional worlds of intricate storylines relaxes viewers. Binge-watching allows them to achieve an intensified fun and thrilling entertainment experience amplified by dramatic moments, empathic character engagement and empathic sadness. Because this mode of viewing long-form serialised texts emphasises the emotionally gratifying enjoying experience, binge-watching is becoming a common way of viewing TV series. Binge-watching is a complex immersion activity in which deeper narrative engagement over an extended time evokes enjoyment. This activity allows the viewer to encounter an audiovisual narrative on a level that is, in many ways, close to reading a novel. Both mediums will enable the audience to get to know the protagonists more profoundly and extensively and to travel the world of fiction for as long as the traveller wants to, that is, until the final resolution is established.

\section{References}

>Advanced Television (2018) Research: US Binge Watches More than Europe. https://advancedtelevision.com/2018/03/27/research-us-binge-watches-more-than-europe/ (1.5.2019). >Ampere Analysis (2018) TV Binge-Watching Increasingly Pronounced in Mature SVOD Markets. https://www.ampereanalysis.com/blog/d1bfada6-523b-41e1-9735-0b11f18d894d (1.5.2019). >Baltar, Fabiola and Brunet, Ignasi (2012) Social Research 2.0: Virtual Snowball Sampling Method Using Facebook. Internet Research 22(1): 57-74. https://doi.org/10.1108/10662241211199960. >Bartsch, Anne (2012) Emotional Gratification in Entertainment Experience: Why Viewers of Movies and Television Series Find it Rewarding to Experience Emotions. Media Psychology 15 (3): 267-302. https://doi.org/10.1080/15213269.2012.693811. 
>Bartsch, Anne; Mangold, Roland; Viehoff, Reinhold and Vorderer, Peter (2006) Emotional Gratifications During Media Use: An Integrative Approach. Communications 31 (3): 261-278. https:// doi.org/10.1515/COMMUN.2006.018.

>Bartsch, Anne and Oliver, Mary Beth (2011) Making Sense of Entertainment: On the Interplay of Emotion and Cognition in Entertainment Experience. Journal of Media Psychology 23 (1): 12-17. https://doi.org/10.1027/1864-1105/a000026.

>Biernacki, Patrick and Waldorf, Dan (1981) Snowball Sampling: Problems and Techniques of Chain Referral Sampling. Sociological Methods \& Research 10 (2): 141-163. https://doi. org/10.1177/004912418101000205.

>Brickman-Bhutta, Christine (2012) Not by the Book: Facebook as a Sampling Frame. Sociological Methods \& Research 41 (1): 57-88. https://doi.org/10.1177/0049124112440795.

>Bryant, Jennings and Miron, Dorina (2002) Entertainment as a Media Effect, pp. 549-582 in Bryant, Jennings and Zillmann, Dolf (eds) Media Effects: Advances in Theory and Research. Mahwah, NJ: Erlbaum.

>Bryant, Jennings; Roskos-Ewoldsen, David and Cantor, Joanne (eds) (2003) Communication and Emotion: Essays in Honor of Dolf Zillmann. Mahwah, NJ: Erlbaum.

$>$ Burroughs, Benjamin (2019) House of Netflix: Streaming Media \& Digital Lore. Popular Communication 17 (1): 1-17. https://doi.org/10.1080/15405702.2017.1343948.

>Busselle, Rick and Bilandzic, Helena (2009) Measuring Narrative Engagement. Media Psychology 12 (4): 321-347. https://doi.org/10.1080/15213260903287259.

>Curtin, Michael; Holt, Jennifer and Sanson, Kevin (2014) Introduction: Making of a Revolution, pp. 1-20 in Curtin, Michael, Holt, Jennifer and Sanson, Kevin (eds) Distribution Revolution: Conversation About the Digital Future of Film and Television. Oakland, CA: University of California Press.

>Deloitte (2018) Digital Media Trends Survey, $12^{\text {th }}$ Edition. https://www2.deloitte.com/insights/us/en/ industry/technology/digital-media-trends-consumption-habits-survey-2018.html (6.6.2019).

$>$ Erickson, Sarah E.; Dal Cin, Sonya and Byl, Hannah (2019) An Experimental Examination of Binge Watching and Narrative Engagement. Social Sciences 8 (1): 19.

https://doi.org/10.3390/socsci8010019.

>Flayelle, Maèva; Maurage, Pierre and Billeux, Joël (2017) Toward a Qualitative Understanding of Binge-Watching Behaviors: A Focus Group Approach. Journal of Behavioral Addictions 6 (4): 457-471. https://doi.org/10.1556/2006.6.2017.060.

>Flayelle, Maèva; Maurage, Pierre; Di Lorenzo, Kim R.; Vögele, Claus; Gainsbury, Sally M. and Billieux, Joël (2020) Binge-Watching: What Do We Know So Far? A First Systematic Review of the Evidence. Current Addiction Reports 7: 44-60. https://doi.org/10.1007/s40429-020-00299-8.

$>$ Green, Melanie C. and Brock, Timothy C. (2000) The Role of Transportation in the Persuasiveness of Public Narratives. Journal of Personality and Social Psychology 79 (5): 701-721. https://doi. org/10.1037//0022-3514.79.5.701.

>Green, Melanie C. and Brock Timothy C. (2002) In the Mind's Eye: Transportation-Imagery Model of Narrative Persuasion, pp. 315-342 in Green, Melanie C.; Strange, Jeffrey J. and Brock Timothy C. (eds) Narrative Impact: Social and Cognitive Foundations. Mahwah, NJ: Erlbaum.

>Hall, Alice, E. and Bracken, Cheryl C. (2011) "I Really Liked That Movie": Testing the Relationship Between Trait Empathy, Transportation, Perceived Realism, and Movie Enjoyment. Journal of Media Psychology 23 (2): 90-99. https://doi.org/10.1027/1864-1105/a000036.

>Haridakis, Paul and Hanson, Gary (2009) Social Interaction and Co-Viewing with YouTube: Blending Mass Communication Reception and Social Connection. Journal of Broadcasting \& Electronic Media 53 (2): 317-335. https://doi.org/10.1080/08838150902908270.

$>$ Harris, Pool (2013) Americans Taking Advantage of the Ability to Watch TV on Their Own Schedules. https://theharrispoll.com/new-york-n-y-april-8-2013-video-on-demand-dvrs-streaming-contententire-seasons-of-television-shows-collected-in-dvd-box-sets-americans-tv-viewing-habits-wereonce-at-the-mercy-of-network/ (7.5.2019). 
>Jenner, Mareike (2015) Binge-Watching: Video-on-Demand, Quality TV, and Mainstreaming Fandom. International Journal of Cultural Studies 20 (3): 304-320. https://doi. org/10.1177/1367877915606485.

>Jones, Scott; Cronin, James and Piacentini, Maria G. (2018) Mapping the Extended Frontiers of Escapism: Binge-Watching and Hyperdiegetic Exploration. Journal of Marketing Management 34 (5-6): 497-508. https://doi.org/10.1080/0267257X.2018.1477818.

$>$ Kaiser, Henry F. (1974) An Index of Factorial Simplicity. Psychometrika 39 (1): 31-36. https://doi. org/10.1007/BF02291575.

>Katz, Elihu; Blumler, Jay G. and Gurevitch, Michael (1973) Uses and Gratifications Research. Public Opinion Quarterly 37 (4): 509-523. https://doi.org/10.1086/268109.

$>$ Kim, Juran and Lee, Ki Hoon (2013) Towards a Theoretical Framework of Motivations and Interactivity for Using IPTV. Journal of Business Research 66 (2): 260-264. https://doi.org/10.1016/j. jbusres.2012.07.004.

>LaRose, Robert (2010) The Problem of Media Habits. Communication Theory 20 (2): 194-222. https:// doi.org/10.1111/j.1468-2885.2010.01360.x.

>Lotz, Amanda (2015) Why 2015 was the Year that Changed TV Forever. https://theconversation.com/ why-2015-was-the-year-that-changed-tv-forever-52422 (25.8.2017).

>McKinley, Christopher J. (2013) Re-Examining the Link Between Cultivation Factors and Viewer Involvement: Investigating Viewing Amount as a Catalyst for the Transportation Process.

Communication Studies 64 (1): 66-85. https://doi.org/10.1080/10510974.2012.731466.

$>$ Mikos, Lothar (2016) Digital Media Platforms and the Use of TV Content: Binge Watching and Video-on-Demand in Germany. Media and Communication 4 (3): 154-161. https://doi.org/10.17645/ mac.v4i3.542.

>Mittell, Jason (2007) Film and Television Narrative, pp. 156-172 in Herman, David (ed.) The Cambridge Companion to Narrative. Cambridge: Cambridge University Press.

$>$ Nakamura, Jeanne and Csikszentmihalyi, Mihaly (2002) The Concept of Flow, pp. 89-105 in Snyder, C. R. and Lopez, Shane J. (eds) Handbook of Positive Psychology. New York: Oxford University Press. $>$ Nell, Victor (1988) The Psychology of Reading for Pleasure: Needs and Gratifications. Reading Research Quarterly 23 (1): 6-50. https://doi.org/10.2307/747903.

$>$ Netflix (2013) Netflix Declares Binge Watching is the New Normal: Study Finds 73\% of TV Streamers Feel Good About it. https://www.prnewswire.com/news-releases/netflix-declares-binge-watchingis-the-new-normal-235713431.html (1.4.2019).

>Oatley, Keith (2011) Such Stuff as Dreams: The Psychology of Fiction. Chichester: Wiley-Blackwell. $>$ Oliver, Mary Beth (1993) Exploring the Paradox of the Enjoyment of Sad Films. Human Communication Research 19(3): 315-342. https://doi.org/10.1111/j.1468-2958.1993.tb00304.x. $>$ Oliver, Mary Beth (2008) Tender Affective States as Predictors of Entertainment Preference. Journal of Communication 58 (1): 40-61. https://doi.org/10.1111/j.1460-2466.2007.00373.x.

>Oliver, Mary Beth and Bartsch, Anne (2010) Appreciation as Audience Response: Exploring Entertainment Gratifications Beyond Hedonism. Human Communication Research 36(1): 53-81. https://doi.org/10.1111/j.1468-2958.2009.01368.x.

>Oliver, Mary Beth and Bartsch, Anne (2011) Appreciation of Entertainment: The Importance of Meaningfulness via Virtue and Wisdom. Journal of Media Psychology 23 (1): 29-33. https://doi. org/10.1027/1864-1105/a000029.

>Oliver, Mary Beth and Hartman, Tilo (2010). Exploring the Role of Meaningful Experiences in Users Appreciation of "Good Movies". Projections 4 (2): 128-150. https://doi.org/10.3167/proj.2010.040208. $>$ Oliver, Mary Beth and Raney, Arthur A. (2011) Entertainment as Pleasurable and Meaningful: Identifying Hedonic and Eudaimonic Motivations for Entertainment Consumption. Journal of Communication 61 (5): 984-1004. https://doi.org/10.1111/j.1460-2466.2011.01585.x. $>$ Panda, Swati and Pandey, Satyendra C. (2017) Binge Watching and College Students: Motivations and Outcomes. Young Consumers 18 (4): 425-438. https://doi.org/10.1108/yc-07-2017-00707. 
>Papacharissi, Zizi and Mendelson, Andrew L. (2007) An Exploratory Study of Reality Appeal: Uses and Gratifications of Reality TV Shows. Journal of Broadcasting \& Electronic Media 51 (2): 355-370. https://doi.org/10.1080/08838150701307152.

>Papacharissi, Zizi and Rubin, Alan M. (2000) Predictors of Internet Use. Journal of Broadcasting \& Electronic Media 44 (2): 175-196. https://doi.org/10.1207/s15506878jobem4402_2.

$>$ Peña, Lesley Lisseth (2015) Breaking Binge: Exploring the Effects of Binge Watching on Television Viewer Reception (Master's Thesis). Dissertations - ALL, paper 283. https://surface.syr.edu/cgi/ viewcontent.cgi?article=1283\&context=etd (3.4.2019).

$>$ Pittman, Matthew and Sheehan, Kim (2015) Sprinting a Media Marathon: Uses and Gratifications of Binge-Watching Television through Netflix. First Monday 20(10). https://doi.org/10.5210/ fm.v20i10.6138.

$>$ Rubenking, Bridget and Bracken, Cheryl C. (2018) Binge-Watching: A Suspenseful, Emotional, Habit. Communication Research Reports 35 (5): 381-391. https://doi.org/10.1080/08824096.2018.152 5346.

>Rubenking, Bridget; Bracken, Cheryl C.; Sandoval, Jennifer and Rister, Alex (2018) Defining New Viewing Behaviours: What Makes and Motivates TV Binge-Watching? International Journal of Digital Television 9 (1): 69-85. https://doi.org/10.1386/jdtv.9.1.69_1.

$>$ Rubin, Alan M. (1983) Television Uses and Gratifications: The Interactions of Viewing Patterns and Motivations. Journal of Broadcasting 27 (1): 37-47. https://doi.org/10.1080/08838158309386471.

$>$ Rubin, Alan M. (2002) The Uses-and-Gratifications Perspective of Media Effects, pp. 525-548 in Bryant, Jennings and Zillmann, Dolf (eds) Media Effects: Advances in Theory and Research. Mahwah, NJ: Erlbaum.

$>$ Rubin, Alan M. and Rubin, Rebecca B. (1981) Age, Context and Television Use. Journal of Broadcasting 25 (1): 1-13. DOI: 0.1080/08838158109386424.

>Rubin, Alan M. and Perse, Elizabeth M. (1987) Audience Activity and Soap Opera Involvement: A Uses and Effects Investigation. Human Communication Research 14 (2): 246-268. https://doi. org/10.1111/j.1468-2958.1987.tb00129.x.

>Sherry, John L. (2004) Flow and Media Enjoyment. Communication Theory 14 (4): 328-347. https:// doi.org/10.1111/j.1468-2885.2004.tb00318.x.

>Shim, Hongjin and Kim, Ki Joon (2018) An Exploration of the Motivations for Binge-Watching and the Role of Individual Differences. Computers in Human Behavior 82: 94-100. https://doi. org/10.1016/j.chb.2017.12.032.

>Slater, Michael D. and Rouner, Donna (2002) Entertainment-Education and Elaboration Likelihood: Understanding the Processing of Narrative Persuasion. Communication Theory 12 (2): 173-191. https://doi.org/10.1111/j.1468-2885.2002.tb00265.x.

>Starosta, Jolanta; Izydorczyk, Bernadetta and Lizińczyk, Sebastian (2019) Characteristics of People's Binge-Watching Behavior in the 'Entering into Early Adulthood' Period of Life. Health Psychology Report 7 (2): 149-164. https://doi.org/10.5114/hpr.2019.83025.

$>$ Steiner, Emil and Xu, Kun (2018). Binge-Watching Motivates Change: Uses and Gratifications of Streaming Video Viewers Challenge Traditional TV Research. To be published in Convergence: The International Journal of Research into New Media Technologies 26 (1), 2020: 82-101 [advanced online publication]. https://doi.org/10.1177/1354856517750365.

>Sung, Yoon Hi; Kang, Eun Yeon and Lee, Wei-Na (2018) Why Do We Indulge? Exploring Motivations for Binge Watching. Journal of Broadcasting \& Electronic Media 6 (23): 408-426. https://doi.org/10.108 0/08838151.2018.1451851.

>Tamborini, Ron; David Bowman, Nicholas; Eden, Alison; Grizzard, Matthew and Organ, Ashley (2010) Defining Media Enjoyment as the Satisfaction of Intrinsic Needs. Journal of Communication 60 (4): 758-777. https://doi.org/10.1111/j.1460-2466.2010.01513.x.

$>$ Tamborini, Ron; Grizzard, Matthew; David Bowman, Nicholas; Reinecke, Leonard; Lewis, Robert J. and Eden, Allison (2011) Media Enjoyment as Need Satisfaction: The Contribution of Hedonic and Nonhedonic Needs. Journal of Communication 61 (6): 1025-1042. https://doi. org/10.1111/j.1460-2466.2011.01593.x. 
>Tukachinsky, Riva and Eyal, Keren (2018) The Psychology of Marathon Television Viewing: Antecedents and Viewer Involvement. Mass Communication and Society 21 (3): 275-295. https://doi. org/10.1080/15205436.2017.1422765.

>Tryon, Chuck (2015) TV Got Better: Netflix's Original Programming Strategies and Binge Viewing. Media Industries Journal 2 (2): 104-116. https://quod.lib.umich.edu/m/mij/15031809.0002.206/--tvgot-better-netflixs-original-programming-strategies?rgn=main;view=fulltext (6.10.2020). $>$ Walton-Pattison, Emily; Dombrowski, Stephan U. and Presseau, Justin (2016) 'Just One More Episode': Frequency and Theoretical Correlates of Television Binge Watching. Journal of Health Psychology 23 (1): 17-24. https://doi.org/10.1177/1359105316643379.

$>$ Wirth, Werner; Hofer, Matthias and Schramm, Holger (2012) Beyond Pleasure: Exploring the Eudaimonic Entertainment Experience. Human Communication Research 3 (4): 406-428. https://doi. org/10.1111/j.1468-2958.2012.01434.x.

$>$ Vaterlaus, Mitchell J.; Spruance, Lori A.; Frantz, Kala and Kruger, Jessica S. (2019) College Student Television Binge Watching: Conceptualization, Gratifications, and Perceived Consequences. To be published in The Social Science Journal 56 (4): 470-479 [advanced online publication]. https://doi. org/10.1016/j.soscij.2018.10.004.

$>$ Vorderer, Peter (2003) Entertainment Theory, pp. 131-153 in Bryant, Jennings; Roskos-Ewoldsen, David and Cantor, Joanne (eds) Communication and Emotion: Essays in Honor of Dolf Zillmann. Mahwah, NJ: Erlbaum.

$>$ Vorderer, Peter; Klimmt, Christoph and Ritterfeld, Ute (2004) Enjoyment: At the Heart of Media Entertainment. Communication Theory 14 (4): 388-408. https://doi.org/10.1111/j.1468-2885.2004. tb00321.x.

$>$ Vorderer, Peter; Steen, Francis F. and Chan, Elaine (2006) Motivation, pp. 3-17 in Bryant, Jennings and Vorderer, Peter (eds) Psychology of Entertainment. Mahwah, NJ: Erlbaum.

>Zillmann, Dolf (1988) Mood Management Through Communication Choices. American Behavioral Scientist 31 (3): 327-340. https://doi.org/10.1177/000276488031003005.

>Zillmann, Dolf (1996) The Psychology of Suspense in Dramatic Exposition, pp. 372-435 in Vorderer, Peter; Wulff, Hans J. and Friedrichsen, Mike (eds) Suspense: Conceptualizations, Theoretical Analyses and Empirical Explorations. Mahwah, NJ: Erlbaum.

>Zillmann, Dolf and Bryant, Jennings (1994) Entertainment as Media Effect, pp. 437-461 in Bryant, Jennings and Zillmann, Dolf (eds) Media effects: Advances in Theory and Research. Mahwah, $\mathrm{NJ}$ : Erlbaum. 


\section{ZAŠTO BAŠ BINGE-WATCHING? ISTAKNUTI MOTIVI I ANALIZA MOTIVIRAJUĆIH HEDONISTIČKIH I EUDAMONIJSKIH ELEMENATA EMOCIONALNOG ZADOVOLJENJA U ISKUSTVU BINGE-WATCHINGA}

\section{Vesna Karuza Podgorelec}

SAŽETAK Binge-watching je popularan oblik medijske konzumacije, a zabava je jedan od izraženih pokretača te aktivnosti. Cilj je istraživanja predočenog u članku istražiti razloge binge-watchinga preispitivanjem etabliranih motiva gledanja televizije, produbljivanjem istraživanja motiva zabave te uvođenjem novoga mogućeg motiva: potrebe za narativnim razumijevanjem. Stoga istraživanje kombinira čimbenike već prije utvrđenih motiva gledanja televizije i čimbenike emocionalnog zadovoljenja hedonističkim i eudamonijskim elementima zabave te uvodi motiv lakšeg praćenja zamršenih linija priče. Rezultati internetskog istraživanja provedenog u Hrvatskoj na 833 sudionika starija od 18 godina pokazuju da su istaknuti motivi binge-watchinga: opuštanje, dobar provod (hedonistički), navika, laganije praćenje zapetljanih linija priče, bijeg i uzbuđenje (hedonistički). Eudamonijski motivi su slabije izraženi od hedonističkih, ali te su skupine motiva u pozitivnoj korelaciji, što upućuje na složenost uživanja u zabavi binge-watchinga.

\section{KLJUČNE RIJEČI}

BINGE-WATCHING, EMOCIONALNO ZADOVOLJENJE, MOTIVI, MEDIJSKE NAVIKE, ISTRAŽIVANJA PUBLIKE

Bilješka o autorici

Vesna Karuza Podgorelec :: Sveučilište Josipa Jurja Strossmayera u Osijeku :: vesnakaruzapodgorelec@gmail.com 